\title{
Synthesis, Crystal Structures and Catalytic Property of Oxidovanadium(V) Complexes with Similar Aroylhydrazones
}

\author{
Min Liang, ${ }^{1, *}$ Nan Sun ${ }^{2}$ and Dong-Hui Zou ${ }^{3}$ \\ ${ }^{1}$ School of Chemistry and Chemical Engineering, Qiqihar University, Qiqihar 161006, P. R. China. \\ ${ }^{2}$ College of Chemistry, Chemical Engineering and Material Science, Shandong Normal University, Jinan 250014, P.R. China \\ ${ }^{3}$ College of Food and Bio-Engineering, Qiqihar University, Qiqihar 161006, P. R. China \\ *Corresponding author: E-mail: liangmin09@163.com
}

Received: 23-07-2018

\begin{abstract}
A pair of new oxidovanadium $(\mathrm{V})$ complexes, $\left[\mathrm{VOL}^{1} \mathrm{~L}\right] \cdot \mathrm{EtOH}(\mathbf{1})$ and $\left[\mathrm{VOL}^{2} \mathrm{~L}\right] \cdot \mathrm{EtOH}(\mathbf{2})(\mathrm{L}=$ acetohydroxamate), derived from the aroylhydrazones $N^{\prime}$-(5-bromo-2-hydroxybenzylidene)-4-methoxybenzohydrazide $\left(\mathrm{H}_{2} \mathrm{~L}^{1}\right)$ and $N^{\prime}$ - $(5$-bromo-2-hydroxybenzylidene)-4-methylbenzohydrazide $\left(\mathrm{H}_{2} \mathrm{~L}^{2}\right)$, have been prepared and characterized by elemental analyses, FT-IR, ${ }^{1} \mathrm{H}$ and ${ }^{13} \mathrm{C}$ NMR spectroscopy and single-crystal structural X-ray diffraction. The complexes have octahedral structures in which the aroylhydrazone ligands behave as binegative donors. Single-crystal structure analyses reveal that the $\mathrm{V}$ centers are coordinated by the donor atoms of the aroylhydrazone ligands, the acetohydroxamate ligands and the oxido groups. Crystal structures of the complexes are stabilized by hydrogen bonds. The complexes function as effective olefin epoxidation catalysts.
\end{abstract}

Keywords: Aroylhydrazone; oxidovanadium complex; catalytic activity; crystal structure

\section{Introduction}

In recent years, remarkable attention has focused on vanadium compounds because of their biochemical significance $^{1}$ and industrial catalytic processes. ${ }^{2}$ For instance, the use of oxovanadium complexes in asymmetric synthesis, ${ }^{3}$ in $\mathrm{C}-\mathrm{C}$ bond formation as well as in $\mathrm{C}-\mathrm{C}, \mathrm{C}-\mathrm{O}$ and $\mathrm{C}-\mathrm{H}$ bond cleavages, ${ }^{4}$ catalytic oxidation of various olefins, ${ }^{5}$ oxidative halogenation and selective epoxidation of unsaturated hydrocarbons and allyl alcohols. ${ }^{6}$ Aroylhydrazones bearing typical $-\mathrm{CO}-\mathrm{NH}-\mathrm{N}=\mathrm{CH}$ - group are interesting ligands in the preparation of various metal complexes which have considerable biological and catalytic properties. ${ }^{7}$ A number of vanadium complexes with various types of ligands have been prepared, yet, those derived from hydrazones only few have been reported with catalytic oxidation on olefins. In this paper we are concerned about the structural investigation and catalytic activity of two vanadium complexes with hydrazone ligands, which have similar structures except for the terminal substituted groups, $\mathrm{Me}$ and OMe. In the present work, a pair of new vanadium $(\mathrm{V})$ complexes $\left[\mathrm{VOL}^{1} \mathrm{~L}\right]$. $\mathrm{EtOH}(\mathbf{1})$ and $\left[\mathrm{VOL}^{2} \mathrm{~L}\right] \cdot \operatorname{EtOH}(2)(\mathrm{L}=$ acetohydroxamate $)$, derived from the aroylhydrazones $N^{\prime}$-(5-bromo-2-hydroxybenzylidene)-4-methoxybenzohydrazide $\left(\mathrm{H}_{2} \mathrm{~L}^{1}\right)$ and $N^{\prime}$ - $(5$ bromo-2-hydroxybenzylidene)-4-methylbenzohydrazide $\left(\mathrm{H}_{2} \mathrm{~L}^{2}\right.$; Scheme 1$)$, are presented.<smiles>[X]c1ccc(C(=O)N/N=C/c2cc(Br)ccc2O)cc1</smiles>

Scheme 1. $\mathrm{H}_{2} \mathrm{~L}^{1}(\mathrm{X}=\mathrm{OMe})$ and $\mathrm{H}_{2} \mathrm{~L}^{2}(\mathrm{X}=\mathrm{Me})$

\section{Experimental}

\subsection{Materials and Methods}

All chemicals and solvents used were of analytical reagent grade and used as received. Micro analyses for $\mathrm{C}$, $\mathrm{H}, \mathrm{N}$ were carried out using a Perkin Elmer $2400 \mathrm{CHNS/O}$ 
elemental analyzer. FT-IR spectra were recorded on a FTIR 8400-Shimadzu as $\mathrm{KBr}$ discs in the range of $400-4000$ $\mathrm{cm}^{-1} .{ }^{1} \mathrm{H}$ and ${ }^{13} \mathrm{C}$ NMR spectra were recorded at $25^{\circ} \mathrm{C}$ on the Bruker AVANCE $300 \mathrm{MHz}$ spectrometer. X-ray diffraction data were collected using a Bruker Smart Apex II diffractometer.

\section{2. Synthesis of the Aroylhydrazones}

An ethanolic solution $(20 \mathrm{~mL})$ containing 5-bromo-2-hydroxybenzaldehyde ( $1.0 \mathrm{mmol}, 0.201 \mathrm{~g}$ ) was added dropwise to the ethanolic solution of 4-methoxybenzohydrazide $(1.0 \mathrm{mmol}, 0.166 \mathrm{~g})$ for $\mathrm{H}_{2} \mathrm{~L}^{1}$, and 4-methylbenzohydrazide ( $1.0 \mathrm{mmol}, 0.150 \mathrm{~g})$ for $\mathrm{H}_{2} \mathrm{~L}^{2}$, respectively, with constant stirring. The mixtures were refluxed for $30 \mathrm{~min}$, and the resulting precipitate was filtered off, washed with cold ethanol and dried in desiccator over silica gel.

$\mathbf{H}_{2} \mathbf{L}^{\mathbf{1}}$ : Yield: $0.29 \mathrm{~g}, 83 \%$. For $\mathrm{C}_{15} \mathrm{H}_{13} \mathrm{BrN}_{2} \mathrm{O}_{3}$ : anal. calcd., \%: C, 51.60; H, 3.75; N, 8.02. Found, \%: C, 51.75; H, 3.83; N, 7.94. FT-IR $(\mathrm{KBr}), \mathrm{cm}^{-1}: v(\mathrm{OH}) 3455, v(\mathrm{NH})$ 3237, $v(\mathrm{CH})$ 2810-3120, $v(\mathrm{C}=\mathrm{O})$ 1647, $v(\mathrm{C}=\mathrm{N})$ 1609, $v(\mathrm{C}-\mathrm{O})$ 1255. ${ }^{1} \mathrm{H}$ NMR $\left(300 \mathrm{MHz}, \mathrm{DMSO}-d^{6}, \mathrm{ppm}\right): \delta=$ 12.08 (s, 1H; OH), 11.38 (s, 1H; NH), 8.59 (s, 1H; CH=N), 7.94 (d, 2H; $\operatorname{ArH}$ ), 7.78 (s, 1H; $\operatorname{Ar} H$ ), 7.43 (d, 1H, $\operatorname{ArH}$ ), 7.08 (d, 2H; $\operatorname{ArH}), 6.90$ (d, $1 \mathrm{H}, \operatorname{ArH}), 3.86\left(\mathrm{~s}, 3 \mathrm{H}, \mathrm{CH}_{3}\right)$. ${ }^{13} \mathrm{C}$ NMR (75 MHz, DMSO- $\left.d^{6}, \mathrm{ppm}\right) \delta=162.24,156.40$, $145.26,133.38,130.58,129.63,124.72,121.32,118.66$, $113.80,110.37,55.46$.

$\mathbf{H}_{2} \mathbf{L}^{2}$ : Yield: $0.30 \mathrm{~g}, 90 \%$. For $\mathrm{C}_{15} \mathrm{H}_{13} \mathrm{BrN}_{2} \mathrm{O}_{2}$ : anal. calcd., \%: C, 54.07; H, 3.93; N, 8.41. Found, \%: C, 54.23; H, 4.02; N, 8.35. FT-IR $(\mathrm{KBr}), \mathrm{cm}^{-1}: v(\mathrm{OH}) 3445, v(\mathrm{NH})$ 3229, $v(\mathrm{CH}) 2815-3120, v(\mathrm{C}=\mathrm{O}) 1647, v(\mathrm{C}=\mathrm{N}) \quad 1617$, $v(\mathrm{C}-\mathrm{O}) 1280 .{ }^{1} \mathrm{H}$ NMR $\left(300 \mathrm{MHz}, \mathrm{DMSO}-d^{6}, \mathrm{ppm}\right): \delta=$ 12.14 (s, 1H; OH), 11.35 (s, 1H; NH), $8.63(\mathrm{~s}, 1 \mathrm{H} ; \mathrm{CH}=\mathrm{N})$, 7.89-7.80 (m, 3H; ArH), 7.47-7.35 (m, 3H, ArH), 6.93 (d, $1 \mathrm{H} ; \mathrm{ArH}), 2.41\left(\mathrm{~s}, 3 \mathrm{H}, \mathrm{CH}_{3}\right) \cdot{ }^{13} \mathrm{C}$ NMR $(75 \mathrm{MHz}$, DMSO- $d^{6}$, ppm) $\delta=162.20,156.38,145.31,142.27,133.35$, $130.22,129.54,126.89,121.32,118.66,113.80,110.37$, 21.12 .

\section{3. Synthesis of the Complexes}

An ethanolic solution $(10 \mathrm{~mL})$ of $\mathrm{VO}(\mathrm{acac})_{2}(0.1$ mmol, $0.026 \mathrm{~g}$ ) was added to the ethanolic solution of acetohydroxamic acid $(0.1 \mathrm{mmol}, 0.0075 \mathrm{~g})$ and $\mathrm{H}_{2} \mathrm{~L}^{1}(0.1$ mmol, $0.035 \mathrm{~g})$ for $\mathbf{1}$ and $\mathrm{H}_{2} \mathrm{~L}^{2}(0.1 \mathrm{mmol}, 0.033 \mathrm{~g})$ for $\mathbf{2}$, respectively, and the resulting orange mixture was refluxed for $30 \mathrm{~min}$. After cooling, the solution was filtered and left to stand overnight. Orange single crystals suitable for crystallographic analysis separated after a week and dried in a vacuum desiccator over silica gel.

[VOL ${ }^{1} \mathbf{L}$ ] - EtOH (1): Yield: 0.027 g, 51\%. For $\mathrm{C}_{19} \mathrm{H}_{21} \mathrm{BrN}_{3} \mathrm{O}_{7} \mathrm{~V}$ : anal. calcd., \%: C, 42.72; $\mathrm{H}, 4.00 ; \mathrm{N}, 7.87$. Found, \%: C, 42.61; H, 3.89; N, 7.78. IR $(\mathrm{KBr}) \mathrm{cm}^{-1}: \mathrm{v}(\mathrm{OH})$ 3427, $v(\mathrm{NH})$ 3217, $v(\mathrm{CH})$ 2820-3100, $v(\mathrm{C}=\mathrm{N})$ 1610,
$v(\mathrm{C}-\mathrm{O}) 1176, v(\mathrm{VO}) 968 .{ }^{1} \mathrm{H}$ NMR $\left(300 \mathrm{MHz}, \mathrm{DMSO}-d^{6}\right.$, ppm): $\delta=14.05(\mathrm{~s}, 1 \mathrm{H} ; \mathrm{NH}), 9.05(\mathrm{~s}, 1 \mathrm{H} ; \mathrm{CH}=\mathrm{N}), 7.99$ (d, 1H; $\operatorname{ArH}$ ), 7.85 (m, 2H; $\operatorname{ArH}), 7.65$ (q, 1H, ArH), 7.03 (d, $2 \mathrm{H} ; \operatorname{ArH}), 6.86(\mathrm{~d}, 1 \mathrm{H}, \mathrm{ArH}), 3.80\left(\mathrm{~s}, 3 \mathrm{H}, \mathrm{OCH}_{3}\right), 2.10$ $\left(\mathrm{t}, 3 \mathrm{H}, \mathrm{CH}_{3}\right.$ ).

[VOL ${ }^{2} \mathbf{L}$ ] $\cdot$ EtOH (2): Yield: 0.022 g, 43\%. For $\mathrm{C}_{19} \mathrm{H}-$ ${ }_{21} \mathrm{BrN}_{3} \mathrm{O}_{6} \mathrm{~V}$ : anal. calcd., \%: C, 44.04; $\mathrm{H}, 4.08 ; \mathrm{N}, 8.11$. Found, \%: C, 43.87; $\mathrm{H}, 4.22 ; \mathrm{N}, 8.27$. IR $(\mathrm{KBr}) \mathrm{cm}^{-1}: v(\mathrm{OH})$ $3434, v(\mathrm{NH})$ 3231, $v(\mathrm{CH})$ 2820-3130, $v(\mathrm{C}=\mathrm{N})$ 1608, $v(\mathrm{C}-\mathrm{O}) 1192, v(\mathrm{VO}) 968 .{ }^{1} \mathrm{H}$ NMR $\left(300 \mathrm{MHz}, \mathrm{DMSO}-d^{6}\right.$, ppm): $\delta=14.06(\mathrm{~s}, 1 \mathrm{H} ; \mathrm{NH}), 9.08(\mathrm{~s}, 1 \mathrm{H} ; \mathrm{CH}=\mathrm{N}), 7.99$ (d, 1H; $\operatorname{ArH}), 7.81$ (m, 2H; ArH), 7.65 (q, 1H, ArH), 7.30 (d, 2H; $\mathrm{ArH}), 6.86(\mathrm{~d}, 1 \mathrm{H}, \mathrm{ArH}), 2.38\left(\mathrm{~s}, 3 \mathrm{H}, \mathrm{CH}_{3}\right), 2.11(\mathrm{t}$, $\left.3 \mathrm{H}, \mathrm{CH}_{3}\right)$.

\section{6. X-Ray structure Determination}

The crystal structures of the complexes were measured on a Bruker SMART Apex II CCD diffractometer using Mo-Ka radiation $(\lambda=0.71073 \AA)$ and a graphite monochromator at $25{ }^{\circ} \mathrm{C}$. Unit cell and reflection data were obtained by standard methods ${ }^{8}$ and are summarized in Table 1. The structures were solved, refined, and prepared for publication using the SHEXTL package (structure solution refinements and molecular graphics), ${ }^{9}$ and using full-matrix least-squares techniques by using $F^{2}$ with anisotropic displacement factors for all non-hydrogen atoms. The amino $\mathrm{H}$ atoms were located from difference Fourier maps and refined isotropically, with N-H distanc-

Table 1. Crystal data and structure refinement for the complexes

\begin{tabular}{|c|c|c|}
\hline Parameters & 1 & 2 \\
\hline Molecular formula & $\mathrm{C}_{19} \mathrm{H}_{21} \mathrm{BrN}_{3} \mathrm{O}_{7} \mathrm{~V}$ & $\mathrm{C}_{19} \mathrm{H}_{21} \mathrm{BrN}_{3} \mathrm{O}_{6} \mathrm{~V}$ \\
\hline Formula weight & 534.24 & 518.24 \\
\hline Temperature (K) & $298(2)$ & $298(2)$ \\
\hline Crystal system & Monoclinic & Monoclinic \\
\hline Space group & $P 2_{1} / n$ & $P 2_{1} / n$ \\
\hline$a(\AA)$ & $8.3528(5)$ & $8.4310(8)$ \\
\hline$b(\AA)$ & $16.0871(10)$ & $15.1788(14)$ \\
\hline$c(\AA)$ & $16.5986(10)$ & $16.8336(16)$ \\
\hline$\beta\left({ }^{\circ}\right)$ & $95.496(2)$ & $93.271(2)$ \\
\hline$V\left(\AA^{3}\right)$ & $2220.1(2)$ & $2150.7(4)$ \\
\hline$Z$ & 4 & 4 \\
\hline$D_{\text {calc }}\left(\mathrm{g} / \mathrm{cm}^{3}\right)$ & 1.598 & 1.600 \\
\hline$\mu\left(\mathrm{mm}^{-1}\right)$ & 2.291 & 2.359 \\
\hline$F(000)$ & 1080 & 1048 \\
\hline Reflections collected & 20456 & 10964 \\
\hline Independent reflection $\left(R_{\text {int }}\right)$ & $4269(0.0554)$ & $3996(0.0242)$ \\
\hline $\begin{array}{l}\text { Reflections observed } \\
(I>2 \sigma(I))\end{array}$ & 3054 & 3278 \\
\hline Data/restraints/parameters & $4269 / 1 / 287$ & $3996 / 1 / 276$ \\
\hline Goodness-of-fit on $F^{2}$ & 1.028 & 1.029 \\
\hline Final $R$ indices $(I>2 \sigma(I))$ & $0.0485,0.1020$ & $0.0342,0.0805$ \\
\hline$R$ indices (all data) & $0.0833,0.1184$ & $0.0470,0.0867$ \\
\hline $\begin{array}{l}\text { Highest peak and deepest } \\
\text { hole }\left(\mathrm{e} \AA^{-3}\right)\end{array}$ & $0.447,-0.425$ & $0.428,-0.365$ \\
\hline
\end{tabular}


es restrained to 0.90(1) $\AA$. Positions of the remaining hydrogen atoms were calculated from the geometry of the molecular skeleton and their thermal displacement parameters were refined isotropically on a groupwise basis. Selected bond lengths and angles are reported in Table 2. $\mathrm{H}$-bonding distances and angles are shown in Table 3.

Table 2. Selected bond lengths $(\AA)$ and angles $\left(^{\circ}\right)$ for the complexes

\begin{tabular}{|c|c|c|c|}
\hline 1 & & & \\
\hline Bond lengths $(\AA)$ & & & \\
\hline $\mathrm{V}(1)-\mathrm{O}(1)$ & $1.861(3)$ & $\mathrm{V}(1)-\mathrm{O}(2)$ & $1.942(3)$ \\
\hline $\mathrm{V}(1)-\mathrm{O}(4)$ & $2.216(3)$ & $\mathrm{V}(1)-\mathrm{O}(5)$ & $1.850(3)$ \\
\hline $\mathrm{V}(1)-\mathrm{O}(6)$ & $1.581(3)$ & $\mathrm{V}(1)-\mathrm{N}(1)$ & $2.080(3)$ \\
\hline Bond angles $\left({ }^{\circ}\right)$ & & & \\
\hline $\mathrm{O}(6)-\mathrm{V}(1)-\mathrm{O}(5)$ & $96.64(14)$ & $\mathrm{O}(6)-\mathrm{V}(1)-\mathrm{O}(1)$ & $99.49(15)$ \\
\hline $\mathrm{O}(5)-\mathrm{V}(1)-\mathrm{O}(1)$ & $105.02(12)$ & $\mathrm{O}(6)-\mathrm{V}(1)-\mathrm{O}(2)$ & $97.41(14)$ \\
\hline $\mathrm{O}(5)-\mathrm{V}(1)-\mathrm{O}(2)$ & $90.35(11)$ & $\mathrm{O}(1)-\mathrm{V}(1)-\mathrm{O}(2)$ & $155.56(12)$ \\
\hline $\mathrm{O}(6)-\mathrm{V}(1)-\mathrm{N}(1)$ & $100.73(14)$ & $\mathrm{O}(5)-\mathrm{V}(1)-\mathrm{N}(1)$ & $158.40(12)$ \\
\hline $\mathrm{O}(1)-\mathrm{V}(1)-\mathrm{N}(1)$ & $84.74(11)$ & $\mathrm{O}(2)-\mathrm{V}(1)-\mathrm{N}(1)$ & $74.84(11)$ \\
\hline $\mathrm{O}(6)-\mathrm{V}(1)-\mathrm{O}(4)$ & $172.74(14)$ & $\mathrm{O}(5)-\mathrm{V}(1)-\mathrm{O}(4)$ & $76.12(11)$ \\
\hline $\mathrm{O}(1)-\mathrm{V}(1)-\mathrm{O}(4)$ & $82.16(12)$ & $\mathrm{O}(2)-\mathrm{V}(1)-\mathrm{O}(4)$ & $83.30(11)$ \\
\hline $\mathrm{N}(1)-\mathrm{V}(1)-\mathrm{O}(4)$ & $86.43(11)$ & & \\
\hline 2 & & & \\
\hline Bond & & & \\
\hline $\mathrm{V}(1)-\mathrm{O}(1)$ & 1.85 & $\mathrm{~V}(1)-\mathrm{O}(2)$ & 1.9 \\
\hline $\mathrm{V}(1)-\mathrm{O}(3)$ & $2.2276(19)$ & $\mathrm{V}(1)-\mathrm{O}(4)$ & $1.8444(18)$ \\
\hline $\mathrm{V}(1)-\mathrm{O}(5)$ & $1.580(2)$ & & \\
\hline $\mathrm{V}(1)-\mathrm{N}(1)$ & $2.080(2)$ & & \\
\hline Bond angles $\left({ }^{\circ}\right)$ & & & \\
\hline $\mathrm{O}(5)-\mathrm{V}(1)-\mathrm{O}(4)$ & $96.43(10)$ & $\mathrm{O}(5)-\mathrm{V}(1)-\mathrm{O}(1)$ & $99.41(11)$ \\
\hline $\mathrm{O}(4)-\mathrm{V}(1)-\mathrm{O}(1)$ & $105.00(8)$ & $\mathrm{O}(5)-\mathrm{V}(1)-\mathrm{O}(2)$ & $97.60(10)$ \\
\hline $\mathrm{O}(4)-\mathrm{V}(1)-\mathrm{O}(2)$ & $90.28(8)$ & $\mathrm{O}(1)-\mathrm{V}(1)-\mathrm{O}(2)$ & $155.59(9)$ \\
\hline $\mathrm{O}(5)-\mathrm{V}(1)-\mathrm{N}(1)$ & $100.43(10)$ & $\mathrm{O}(4)-\mathrm{V}(1)-\mathrm{N}(1)$ & $158.73(8)$ \\
\hline $\mathrm{O}(1)-\mathrm{V}(1)-\mathrm{N}(1)$ & $84.99(8)$ & $\mathrm{O}(2)-\mathrm{V}(1)-\mathrm{N}(1)$ & $74.79(8)$ \\
\hline $\mathrm{O}(5)-\mathrm{V}(1)-\mathrm{O}(3)$ & $172.15(10)$ & $\mathrm{O}(4)-\mathrm{V}(1)-\mathrm{O}(3)$ & $75.72(7)$ \\
\hline $\mathrm{O}(1)-\mathrm{V}(1)-\mathrm{O}(3)$ & $82.97(8)$ & $\mathrm{O}(2)-\mathrm{V}(1)-\mathrm{O}(3)$ & $82.53(8)$ \\
\hline $\mathrm{N}(1)-\mathrm{V}(1)-\mathrm{O}(3)$ & $87.20(7)$ & & \\
\hline
\end{tabular}

Table 3. Hydrogen bonding interactions $\left(\AA ̊{ }^{\circ}\right)$

\begin{tabular}{llllc}
\hline $\boldsymbol{D}-\mathrm{H} \cdots \boldsymbol{A}$ & $\boldsymbol{d}(\boldsymbol{D}-\mathrm{H})$ & $\boldsymbol{d}(\mathrm{H} \cdots \boldsymbol{A})$ & $\boldsymbol{d}(\boldsymbol{D} \cdots \boldsymbol{A})$ & $\begin{array}{c}\text { Angle } \\
(\boldsymbol{D}-\mathrm{H} \cdots \boldsymbol{A})\end{array}$ \\
\hline $\mathbf{1}$ & & & & \\
$\mathrm{N}(3)-\mathrm{H}(3) \cdots \mathrm{O}(7)$ & $0.90(1)$ & $1.85(3)$ & $2.697(5)$ & $156(6)$ \\
$\mathrm{O}(7)-\mathrm{H}(7) \cdots \mathrm{N}(2)^{\mathrm{i}}$ & 0.82 & $2.00(3)$ & $2.814(5)$ & $176(5)$ \\
$\mathbf{2}$ & & & & \\
$\mathrm{O}(6)-\mathrm{H}(6) \cdots \mathrm{N}(2)^{\mathrm{ii}}$ & 0.82 & 2.02 & $2.839(3)$ & $172(5)$ \\
$\mathrm{N}(3)-\mathrm{H}(3) \cdots \mathrm{O}(6)$ & $0.90(1)$ & $1.82(2)$ & $2.697(3)$ & $163(4)$ \\
\hline
\end{tabular}

Symmetry codes: i) $x+1 / 2,-y+3 / 2, z-1 / 2$; ii) $1 / 2+x, 3 / 2-y,-1 / 2+z$.

\section{7. Catalytic Epoxidation of Olefins}

To a solution of olefins $(0.28 \mathrm{mmol}), \mathrm{NaHCO}_{3}(0.11$ $\mathrm{mmol}, 9.24 \mathrm{mg})$ and catalyst $\left(9.4 \times 10^{-4} \mathrm{mmol}\right)$ in the mixture of $\mathrm{CH}_{3} \mathrm{OH} / \mathrm{CH}_{2} \mathrm{Cl}_{2}(1.2 \mathrm{~mL} ; \mathrm{V}: \mathrm{V}=7: 3)$ was added
$\mathrm{H}_{2} \mathrm{O}_{2}$ (1.1 mmol, $30 \% \mathrm{H}_{2} \mathrm{O}_{2}$ in water) as oxidant. After the reaction was over at $74.5 \mathrm{~min}$, for the products analysis, the solution was subjected to multiple ether extraction, and the extract was also concentrated down to $0.5 \mathrm{~mL}$ by distillation in a rotary evaporator at room temperature and then a sample $(2 \mu \mathrm{L})$ was taken from the solution and analyzed by GC. The retention times of the peaks were compared with those of commercial standards, and chlorobenzene was used as an internal standard for GC yield calculation.

\section{Results and Discussion}

\section{1. Synthesis and Characterization}

The reaction of $\mathrm{VO}(\mathrm{acac})_{2}$ and acetohydroxamic acid with the tridentate aroylhydrazone ligands $\mathrm{H}_{2} \mathrm{~L}^{1}$ and $\mathrm{H}_{2} \mathrm{~L}^{2}$ in ethanol led to the formation of the complexes. Crystals of the complexes are stable at room temperature and soluble in DMSO, DMF, ethanol, acetonitrile and less soluble in other common solvents like dichloromethane, chloroform, and insoluble in benzene, $n$-hexane and $\mathrm{CCl}_{4}$.

\section{2. ${ }^{1} \mathrm{H}$ NMR Spectra}

${ }^{1} \mathrm{H}$ NMR data of the aroylhydrazone ligands when compared with the complexes reveal that the ligands serve as tridentate binegative $\mathrm{ONO}$ donor. The azomethine $\mathrm{C}-\mathrm{H}$ signal in the complexes is shifted up-field from its original position in the free ligands upon coordination of the $\mathrm{CH}=\mathrm{N}$ - groups, on account of reduction of electron density at the azomethine $\mathrm{C}-\mathrm{H}$. The aromatic protons also show some deviation in the complexes as compared to the free ligand since in the complexes they are in direct conjugation to the coordinated $\mathrm{O}$ and $\mathrm{N}$ of the hydrazone ligands.

\subsection{IR Spectra}

IR spectra of the free aroylhydrazone ligands show bands at $3220-3240 \mathrm{~cm}^{-1}$ for $v(\mathrm{~N}-\mathrm{H}), 1647 \mathrm{~cm}^{-1}$ for $v(\mathrm{C}=\mathrm{O})$ and $3445-3455 \mathrm{~cm}^{-1}$ for $v(\mathrm{O}-\mathrm{H}){ }^{10}$ The $v(\mathrm{C}=\mathrm{O})$ bands are absent in the spectra of the complexes as the ligands bind in binegative mode losing protons from the carbohydrazide groups. The strong peak at about 1610 $\mathrm{cm}^{-1}$ can be assigned to $v(\mathrm{C}=\mathrm{N}) .{ }^{11}$ The complexes exhibit characteristic bands at $968 \mathrm{~cm}^{-1}$ for the stretching of $\mathrm{V}=\mathrm{O}$ groups. ${ }^{12}$

\section{4. Structure Description}

The perspective views of the complexes together with the atom numbering schemes are shown in Figs. 1 and 2. The asymmetric units of the complexes contain one complex molecule and one ethanol molecule. The coordination geometry around each $\mathrm{V}$ atom reveals a distorted 
octahedral environment with an $\mathrm{NO}_{5}$ chromophore. The ligand molecule behaves as binegative tridentate one binding through the phenolate oxygen, the enolate oxygen and the imine nitrogen and occupies three positions in the basal plane. The fourth donor of the basal plane is furnished by the hydroxyl $\mathrm{O}$ atom of the acetohydroxamate ligand. The oxo group and the carbonyl $\mathrm{O}$ atom of the acetohydroxamate ligand are located at the axial positions. The $\mathrm{V}$ atoms are found to be deviated from the corresponding mean basal planes by 0.283(2) Å for $\mathbf{1}$ and 0.279(2) Å for $\mathbf{2}$. The $\mathrm{C}(8)-\mathrm{O}(2)$ bond lengths are closer to single bond length rather than $\mathrm{C}-\mathrm{O}$ double bond length. However, the shorter length compared to $\mathrm{C}-\mathrm{O}$ single bond may be attributed to extended electron delocalization in the ligand. Similarly shortening of $\mathrm{C}(8)-\mathrm{N}(2)$ bond lengths together with the elongation of $\mathrm{N}(1)-\mathrm{N}(2)$ lengths also supports the electron cloud delocalization in the ligand system. The ligand molecules form five-membered and six-membered chelate rings with the $\mathrm{V}$ centers. The bond lengths related to the $\mathrm{V}$ atoms are similar to those observed in other vanadium complexes. ${ }^{13}$ In the crystal structures of the complexes, the vanadium complex molecules are linked by ethanol molecules through hydrogen bonds (Figs. 3 and 4).

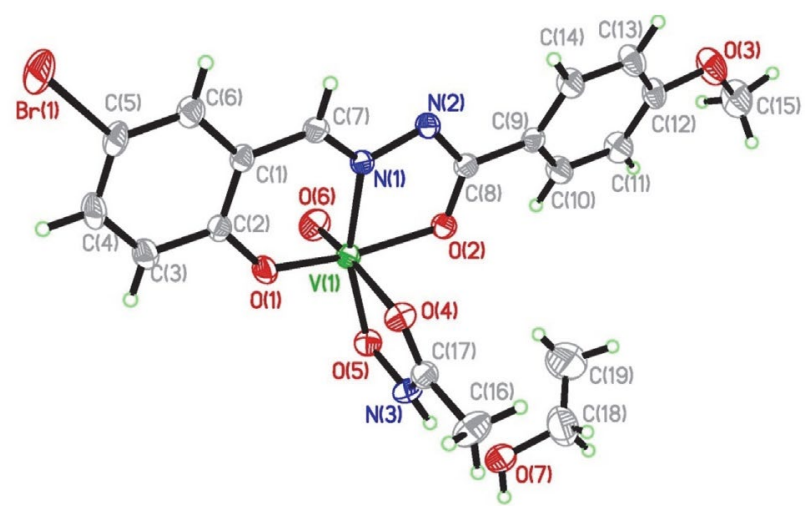

Figure 1. An ORTEP diagram of complex 1 with atom labeling scheme and 30\% probability thermal ellipsoids for all non-hydrogen atoms. Hydrogen bonds are shown as dashed lines.

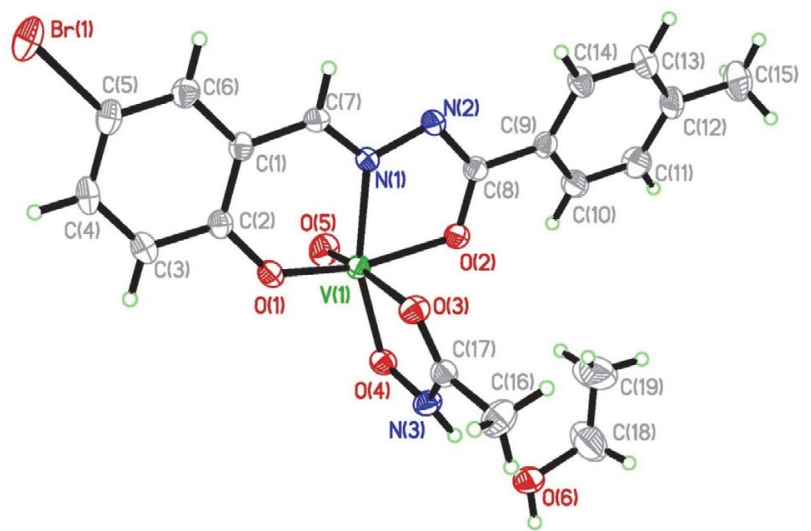

Figure 2. An ORTEP diagram of complex 2 with atom labeling scheme and $30 \%$ probability thermal ellipsoids for all non-hydrogen atoms. Hydrogen bonds are shown as dashed lines.

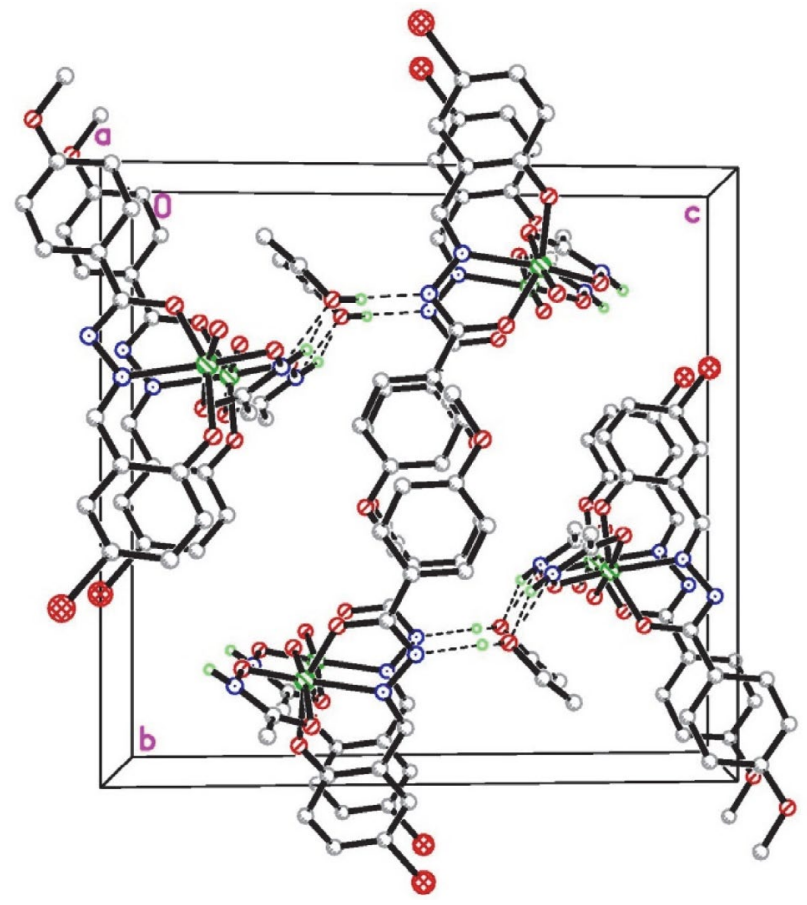

Figure 3. Hydrogen bonds linked structures of complex 1.

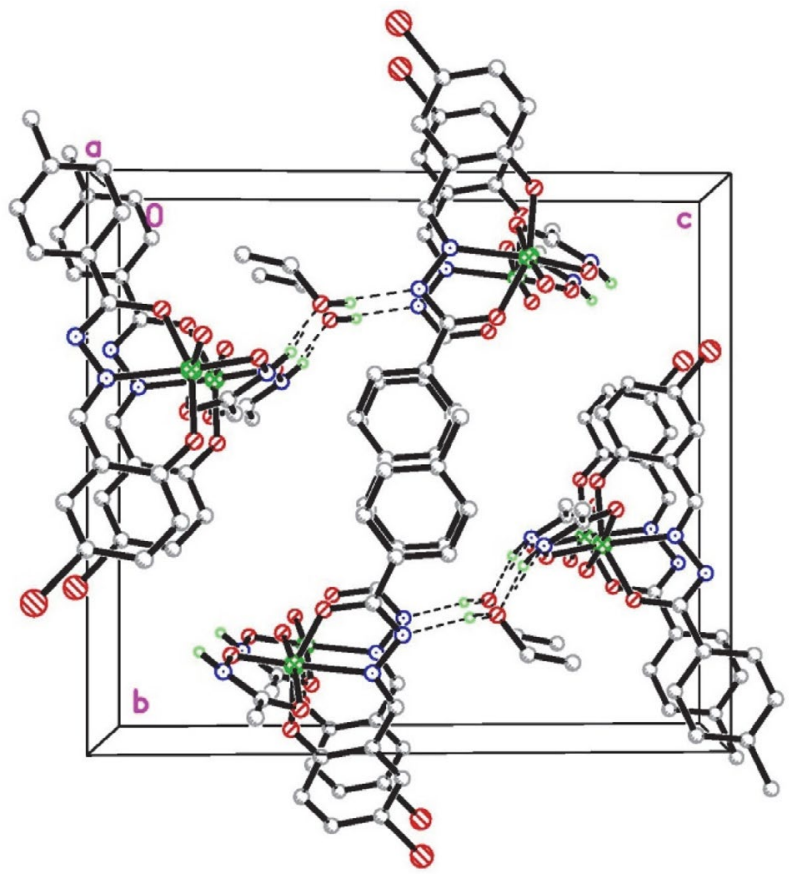

Figure 4. Hydrogen bonds linked structures of complex 2.

\section{5. Catalytic Property}

The reactions were performed in (70:30) mixture of $\mathrm{CH}_{3} \mathrm{OH} / \mathrm{CH}_{2} \mathrm{Cl}_{2}(1.2 \mathrm{~mL})$ under air at room temperature. The molar ratios for catalyst:substrate: $\mathrm{NaHCO}_{3}: \mathrm{H}_{2} \mathrm{O}_{2}$ are 1:298:117:1170. The GC conversion (\%) is measured relative to the starting olefin after $74.5 \mathrm{~min}$. The complexes show effective catalytic property in the oxidation of various olefins to their corresponding epoxides. The details of cata- 
lytic properties with respect to epoxidation of olefins with the complexes as catalysts are given in Table 4. Excellent epoxide yields and selectivity (>99\%) were observed for all aliphatic and aromatic substrates. The results of catalytic studies using the catalysts reveal that the efficiency of catalyst toward all the substrates is similar with maximum conversion, TON, and selectivity. When $\mathrm{H}_{2} \mathrm{O}_{2}(1.1 \mathrm{mmol}, 30 \%$ $\mathrm{H}_{2} \mathrm{O}_{2}$ in water) was used as a sole oxidant the catalytic efficiency is not high, but when $\mathrm{NaHCO}_{3}(0.11 \mathrm{mmol}, 9.24$ $\mathrm{mg}$ ) was added as a co-catalyst the efficiency of the system increases many times. The key aspect of such a reaction is that $\mathrm{H}_{2} \mathrm{O}_{2}$ and hydrogen carbonate react in an equilibrium process to produce peroxymonocarbonate, $\mathrm{HCO}_{4}^{-}$, which is a more reactive nucleophile than $\mathrm{H}_{2} \mathrm{O}_{2}$ and speeds up the epoxidation reaction. The catalytic properties of the presented complexes are comparable to the molybdenum and vanadium complexes reported in literature. ${ }^{14}$

Table 4. The catalytic oxidation results

\begin{tabular}{lll} 
Substrate & $\begin{array}{l}\text { Conversion } \\
(\%)(\mathrm{TON})^{\mathbf{a}}\end{array}$ \\
\hline
\end{tabular}

${ }^{\mathrm{a}} \mathrm{TON}=(\mathrm{mmol}$ of product $) / \mathrm{mmol}$ of catalyst.

\section{Conclusion}

A pair of new oxidovanadium $(\mathrm{V})$ complexes with aroylhydrazone ligands have been prepared and structurally characterized using X-ray structure analysis, FT-IR and ${ }^{1} \mathrm{H}$ NMR spectra. The complexes have octahedral geometry with positions around the central atom being occupied with donor atoms of the aroylhydrazone ligand, the acetohydroxamate ligand and one oxo group. The complexes show effective catalytic property in the oxidation of various olefins to their corresponding epoxides.

\section{Supplementary Material}

CCDC reference numbers 1845890 and 1845891 contain the supplementary crystallographic data for this article. These data can be obtained free of charge at http:// www.ccdc.cam.ac.uk, or from Cambridge Crystallographic Data Center, 12 Union Road, Cambridge CB2 1EZ, UK; Fax: +44 1223336 033; Email: deposit@ccdc.cam.ac.uk.

\section{References}

1. (a) C. Rozzo, D. Sanna, E. Garribba, M. Serra, A. Cantara, G. Palmieri, M. Pisano, J. Inorg. Biochem. 2017, 174, 14-24; DOI:10.1016/j.jinorgbio.2017.05.010

(b) T. Jakusch, T. Kiss, Coord. Chem. Rev. 2017, 351, 118-126; DOI:10.1016/j.ccr.2017.04.007

(c) S. Sultan, U. Ashiq, R. A. Jamal, M. Mahroof-Tahir, Z. Shaikh, B. Shamshad, M. Lateef, L. Iqbal, Biometals 2017, 30, 873-891; DOI:10.1007/s10534-017-0054-6

(d) S. Kumar, A. Syed, S. Andotra, R. Kaur, Vikas, S. K. Pandey, J. Mol. Struct. 2018, 1154, 165-178.

DOI:10.1016/j.molstruc.2017.10.009

2. (a) V. K. Singh, A. Maurya, N. Kesharvani, P. Kachhap, S. Kumari, A. K. Mahato, V. K. Mishra, C. Haldar, J. Coord. Chem. 2018, 71, 520-541; DOI:10.1080/00958972.2018.1434516

(b) I. Gryca, K. Czerwinska, B. Machura, A. Chrobok, L. S. Shulpina, M. L. Kuznetsov, D. S. Nesterov, Y. N. Kozlov, A. J. L. Pombeiro, I. A. Varyan, G. B. Shulpin, Inorg. Chem. 2018, 57, 1824-1839; DOI:10.1021/acs.inorgchem.7b02684

(c) J. C. Pessoa, M. R. Maurya, Inorg. Chim. Acta 2017, 455, 415-428; DOI:10.1016/j.ica.2016.04.012

(d) R. N. Senapati, P. Dutta, S. Rana, K. M. Parida, S. Sahu, A. Sarkar, Inorg. Nano-Met. Chem. 2017, 47, 1429-1435;

(e) R. C. Dey, M. M. Islam, M. Halder, A. S. Roy, S. M. Islam, Chemistryselect 2016, 1, 6797-6804.

DOI:10.1002/slct.201601369

3. (a) P. Kelly, S. E. Lawrence, A. R. Maguire, Eur. J. Org. Chem. 2006, 19, 4500-4509; DOI:10.1002/ejoc.200600320

(b) Y. N. Belokon, W. Clegg, R. W. Harrington, C. Young, M. North, Tetrahedron 2007, 63, 5287-5299;

DOI:10.1016/j.tet.2007.03.140

(c) N. U. H. Khan, S. Agrawal, R. I. Kureshy, S. H. R. Abdi, V. J. Mayani, R. V. Jasra, Eur. J. Org. Chem. 2006, 14, 3175-3180; DOI:10.1002/ejoc.200600208

(d) Y. N. Belokon, M. North, T. Parsons, Org. Lett. 2000, 2, 1617-1619. DOI:10.1021/ol005893e

4. (a) Y. Kataoka, I. Makihira, T. Yamagata, K. Tani, Organometallics 1997, 16, 4788-4795; DOI:10.1021/om970545a

(b) S. Ghorai, C. Mukherjee, Chem. Commun. 2012, 48, 10180-10182; DOI:10.1039/c2cc35963d

(c) C. Milsmann, S. P. Semproni, P. J. Chirik, J. Am. Chem. Soc. 2014, 136, 12099-12107; DOI:10.1021/ja5062196

(d) D. R. Wang, A. Behrens, M. Farahbakhsh, J. Gatjens, D. Rehder, Chem. Eur. J. 2003, 9, 1805-1813;

DOI: $10.1002 /$ chem.200390207

(e) F. Franceschi, E. Solari, C. Floriani, M. Rosi, A. Chiesi-Villa, C. Rizzoli, Chem. Eur. J. 1999, 5, 708-721.

DOI:10.1002/(SICI)1521-3765(19990201)5:2<708::AIDCHEM708>3.0.CO;2-I 
5. (a) M. L. Kuznetsov, J. C. Pessoa, Dalton Trans. 2009, 28, 5460-5468; DOI:10.1039/b902424g

(b) R. Hajian, S. Tangestaninejad, M. Moghadam, V. Mirkhani, I. Mohammadpoor-Baltork, A. R. Khosropour, J. Coord. Chem. 2011, 64, 4134-4144;

DOI:10.1080/00958972.2011.636038

(c) K. Nomura, S. Zhang, Chem. Rev. 2011, 111, 2342-2362; DOI:10.1021/cr100207h

(d) G. Romanowski, J. Kira, M. Wera, Polyhedron 2014, 67, 529-539. DOI:10.1016/j.poly.2013.10.008

6. (a) S. Rana, B. Pandey, A. Dey, R. Haque, G. Rajaraman, D. Maiti, ChemCatChem 2016, 8, 3367-3374;

DOI: $10.1002 /$ cctc. 201600843

(b) M. Zhao, J. T. Mohr, Tetrahedron 2017, 73, 4115-4124; DOI:10.1016/j.tet.2016.12.055

(c) S. Rana, R. Haque, G. Santosh, D. Maiti, Inorg. Chem. 2013, 52, 2927-2932; DOI:10.1021/ic302611a

(d) N. Mizuno, Y. Nakagawa, K. Yamaguchi, J. Mol. Catal. A 2006, 251, 286-290. DOI:10.1016/j.molcata.2006.02.012

7. (a) S. Parveen, S. Govindarajan, H. Puschmann, R. Revathi, Inorg. Chim. Acta 2018, 477, 66-74;

DOI:10.1016/j.ica.2018.02.022

(b) M. Sennappan, P. M. Krishna, A. A. Hosamani, R. H. Krishna, J. Mol. Struct. 2018, 1164, 271-279;

DOI:10.1016/j.molstruc.2018.03.054

(c) J. E. Philip, S. A. Antony, S. J. Eeettinilkunnathil, M. R. P. Kurup, M. P. Velayudhan, Inorg. Chim. Acta 2018, 469, 87-97; DOI:10.1016/j.ica.2017.09.006

(d) Z. L. You, H. Y. Yu, B. Y. Zheng, C. L. Zhang, C. W. Lv, K. Li, L. Pan, Inorg. Chim. Acta 2018, 469, 44-50;

DOI:10.1016/j.ica.2017.09.011

(e) M. A. Naziri, E. Sahin, N. Seferoglu, B. Shaabani, J. Coord. Chem. 2018, 71, 89-103.

DOI:10.1080/00958972.2018.1432857

8. (a) Brukewwwwwr, SMART (Version 5. 624) and SAINT (Version 6. 04) Programs Using the Windows NT System, Bruker AXS Inc., Madison, WI, USA, 2001; (b) G. M. Sheldrick, Acta Crystallogr. 2008, A64, 112-122. DOI:10.1107/S0108767307043930

9. G. M. Sheldrick, SHELXTL, Version 5.10, Bruker AXS Inc., Madison, WI, USA, 1997.

10. (a) E. Kwiatkowski, G. Romanowski, W. Nowicki, M. Kwiatkowski, K. Suwinska, Polyhedron 2003, 22, 1009-1018; DOI:10.1016/S0277-5387(03)00041-X

(b) A. R. Yaul, G. B. Pethe, A. S. Aswar, Russ. J. Coord. Chem. 2010, 36, 254-258. DOI:10.1134/S1070328410040032

11. D. Sadhukhan, M. Maiti, E. Zangrando, S. Pathan, S. Mitra, A. Patel, Polyhedron 2014, 69, 1-9.

DOI:10.1016/j.poly.2013.11.007

12. A. Sarkar, S. Pal, Polyhedron 2006, 25, 1689-1694. DOI:10.1016/j.poly.2005.11.009

13. (a) J.-X. Lei, J. Wang, Y. Huo, Z. You, Acta Chim. Slov. 2016, 63, 670-677; DOI:10.17344/acsi.2016.2589

(b) Q. Liu, J. Lin, J. Liu, W. Chen, Y. Cui, Acta Chim. Slov. 2016, 63, 279-286;

(c) Z.-Q. Han, S. Han, Y. Wang, Acta Chim. Slov. 2016, 63, 200-203; DOI:10.17344/acsi.2016.2266

(d) S. Guo, N. Sun, Y. Ding, A. Li, Y. Jiang, W. Zhai, Z. Li, D. Qu, Z. You, Z. Anorg. Allg. Chem. 2018, 644, 1172-1176; DOI:10.1002/zaac.201800060

(e) L. Li, K.-W. Lv, Y.-T. Li, G.-F. Jiang, Y. Xin, L. Ye, Y. Zhang, H. Liu, C.-H. Shang, Z.-L. You, Chinese J. Inorg. Chem. 2017, 33, 905-912.

14. (a) M. Liang, D.-H. Zou, Acta Chim. Slov. 2016, 63, 180-185; DOI:10.17344/acsi.2015.2169

(b) L. Wang, Y.-J. Han, Q.-B. Li, L.-W. Xue, Acta Chim. Slov. 2016, 63, 822-826; DOI:10.17344/acsi.2016.2699

(c) T. Jakusch, K. Kozma, E. A. Enyedy, N. V. May, A. Roller, C. R. Kowol, B. K. Keppler, T. Kiss, Inorg. Chim. Acta 2018, 472, 243-253; DOI:10.1016/j.ica.2017.08.018

(d) E. Kober, Z. Janas, J. Jezierska, Inorg. Chem. 2016, 55, 10888-10898; DOI:10.1021/acs.inorgchem.6b01283

(e) A.-M. Li, J. Coord. Chem. 2014, 67, 2076-2085.

DOI:10.1080/00958972.2014.931577

\section{Povzetek}

Sintetizirali smo dva nova oksidovanadijeva(V) kompleksa, $\left[\mathrm{VOL}^{1} \mathrm{~L}\right] \cdot \mathrm{EtOH}(\mathbf{1})$ in $\left[\mathrm{VOL}^{2} \mathrm{~L}\right] \cdot \mathrm{EtOH}(\mathbf{2})(\mathrm{L}=$ acetohidroksamat), pripravljenega iz aroilhidrazona $N^{\prime}$-(5-bromo-2-hidroksibenziliden)-4-metoksibenzohidrazida $\left(\mathrm{H}_{2} \mathrm{~L}^{1}\right)$ in $N^{\prime}$-(5-bromo-2-hidroksibenziliden)-4-metilbenzohidrazida $\left(\mathrm{H}_{2} \mathrm{~L}^{2}\right)$ ter ju okarakterizirali z elementno analizo, FT-IR, ${ }^{1} \mathrm{H}$ in ${ }^{13} \mathrm{C}$ NMR spektroskopijo in monokristalno rentgensko strukturno difrakcijo. Kompleksa imata oktaedrično strukturo, v kateri je aroilhidrazonski ligand dianion. Monokristalna strukturna analiza razkrije, da je V center koordiniran $\mathrm{z}$ donorskimi atomi aroilhidrazonskega liganda, acetohidroksamatnega liganda in oksido skupino. Kristalna struktura kompleksov je stabilizirana z vodikovimi vezmi. Kompleksa sta učinkovita katalizatorja za epoksidacijo olefinov. 